\title{
CULTURE OPENNESS AS AN ELEMENT OF POSITIVE POTENTIAL OF ENTERPRISES IN A CRIRIS SITUATION
}

\author{
Katarzyna Szymańska ${ }^{\mathrm{a}}$, Anna Walecka \\ Lodz University of Technology, Lodz, Poland \\ a e-mail: katarzyna.szymanska@p.lodz.pl \\ b e-mail: anna.walecka@p.lodz.pl
}

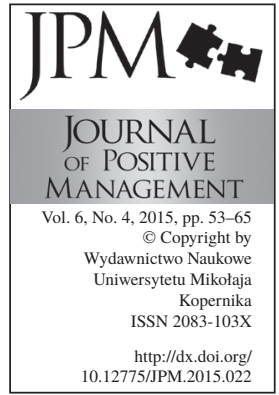

\begin{abstract}
The paper presents the results of the study on the importance of open organisational culture as an element of positive potential of an enterprise in a crisis situation. The aim of the study was to demonstrate the link between the open organisational culture as part of the organisation's positive potential and the kind of crisis occurring in the enterprise. To achieve the research objective, the results of the pilot study carried out in 2015 among enterprises in different types of crisis were used. The results show that building the open organisational culture which is part of the positive potential of the organisation is one of the key elements of entrepreneurial activity. In the light of the results obtained, it can be said that modern enterprises need to deal with various problems generated by their dynamically changing environment. In such situations, it is important to make certain changes in organisational culture while taking remedial (anti-crisis) action.
\end{abstract}

Keywords: open organisational culture, positive potential of enterprises, crisis in the enterprise

Paper type: Conceptual paper

\section{Introduction}

In recent years, various positive phenomena and processes that occur in organisations and contribute to their dynamic development have been identified, analysed, promoted and disseminated. One of them is the positive potential of the organisation, which is a set of theories that are focused on the behaviour of employees. This capacity can be created in different ways. It is related to research trends focused on positive relationships, personal development and well-being of employees, as well as positive leadership and practices in human resources management that foster positive organisational phenomena (Cameron, 2008; Glińska-Neweś and Haffer, 2014). Studies in this area identify several elements that affect the organisation's ability to create its positive potential. Hence, the term of the positive potential covers states, levels and configurations of resources (tangible and intangible) which stimulate the positive organisational climate as well as the positive organisational culture and are conducive to the positive, pro- 
CULTURE OPENNESS AS AN ELEMENT

OF POSITIVE

Katarzyna Szymańska

Anna Walecka developmental behaviour of employees, ultimately contributing to the development of the organisation and the improvement of its performance (Glińska-Neweś, 2010).

Therefore, it can be concluded that there is a close relationship between the positive potential and the organisational culture that needs to have characteristics of openness to be able to contribute to the development and changes in the organisation. In this case, the said open organisational culture is to integrate participants in the organisation, i.e. owners, managers and employees, around positive actions. Thus, there is a confirmed consensus that organisational culture determines the behaviour of members of the organisation, making the organisation more or less open to and responsive to changes in a dynamically changing environment. Different crisis situations, in particular, are the key process forcing organisations to embrace change. The aim of the paper is therefore an attempt to demonstrate the relationship between the open organisational culture as part of the positive potential of the organisation and the type of crisis occurring in the enterprise.

To achieve the research objective, the results of the pilot study carried out in 2015 among enterprises experiencing different types of crisis were used.

The study included 50 companies located in Central Poland. The diagnostic survey method, with the use of the handed-out questionnaire technique, was selected as the research method.

\section{Open organisational culture and positive organisational potential}

According to Cameron, Dutton and Quinn, the positive trend in management sciences encompasses research on: positive features of the organisation and its members, positive processes that occur in organisations and results that can be achieved by organisations in their operations (Cameron et al., 2003). The main interests of researchers of this trend include phenomena which members of the organisation experience such as: happiness, excellence, vitality, a sense of flourishing or uplifting. The so-called generative processes, generating and enhancing the creative (generative) potential of employees, are the most interesting processes that occur in the organisation. This potential, enriching individual capacities of members of the organisation, allows the creation of innovative solutions and the achievement of superior results, which in turn contributes to reaching personal goals and aspirations of employees and to the development of the entire organisation. The prerequisite for the existence of creative processes in an organisation is experiencing positive emotions by employees in the workplace. These emotions motivate to achieve excellence and outstanding results and are conducive to expanding the horizons of thinking and creative experimentation. The emergence of positive emotions in employees is part of the so-called "positive spiral" in the organisation; positive emotions are conducive to feeling positive 
energy, which translates into a commitment to increase the efficiency of the entire organisation, and this in turn is a catalyst for triggering further positive emotions in employees. This is especially important in the era of rapid changes and various crises that may occur within the organisation and beyond. The concept of the positive potential of the organisation is closely connected with the principles referring to human nature. Each of the presented principles is related to the values that express the belief and conviction about what is really important and right for the human being.

Such an approach enables the identification of organisational culture as one of the components of the positive potential of the organisation. Organisational culture should be understood as a common set of beliefs, values, norms and customs that control the behaviour of members of the organisation. It is specific to each organisation and shaped largely by the management. It is reflected in overt as well as hidden dimensions of the organisation and determines patterns of exploring and interpreting reality (see: Wong, 2005; Yeh et al., 2006; Kulkarni et al., 2007; Chong et al., 2009). The main principles of the positive concept of the organisation and related values that constitute a component of organisational culture are presented in Table 1.

\begin{tabular}{|c|c|c|c|}
\hline \multicolumn{4}{|c|}{ Principles } \\
\hline $\begin{array}{l}\text { Every man pursues } \\
\text { happiness in life and } \\
\text { tries to do good thro- } \\
\text { ugh his or her actions }\end{array}$ & $\begin{array}{l}\text { Pursuit of excellence } \\
\text { and superiority is part } \\
\text { of human nature }\end{array}$ & $\begin{array}{l}\text { In order to achie- } \\
\text { ve excellence and } \\
\text { outstanding results } \\
\text { in his or her work, } \\
\text { every individual needs } \\
\text { positive and creative } \\
\text { energy }\end{array}$ & $\begin{array}{l}\text { Employees through } \\
\text { their experience in } \\
\text { the organisation build } \\
\text { positive relationships } \\
\text { with co-workers } \\
\text { and the organisation } \\
\text { as such }\end{array}$ \\
\hline \multicolumn{4}{|c|}{ Values } \\
\hline $\begin{array}{l}\text { honesty, generosity, } \\
\text { fairness, respect for } \\
\text { the truth, } \\
\text { courage }\end{array}$ & $\begin{array}{l}\text { perfection, } \\
\text { responsibility, } \\
\text { involvement, } \\
\text { rationality, } \\
\text { congeniality }\end{array}$ & $\begin{array}{l}\text { openness, pro-activity, } \\
\text { adaptability, } \\
\text { creativity }\end{array}$ & $\begin{array}{l}\text { respect, } \\
\text { trust, } \\
\text { cooperation, } \\
\text { loyalty, } \\
\text { respect for organisa- } \\
\text { tional traditions }\end{array}$ \\
\hline
\end{tabular}

Assessing the above-mentioned values and principles, it can be said that building the positive organisational potential requires the application of solutions in which the culture and the positive potential of the organisation intertwine. According to Cameron, Dutton and Quinn, the positive trend in management sciences is focused on the study of positive features of the organisation and its members, as well as positive processes occurring in organisations and the results
CULTURE OPENNESS AS AN ELEMENT OF POSITIVE

Katarzyna Szymańska Anna Walecka

Table 1. The main principles of the positive concept of the organisation and related values

Source: The authors' own compilation. 
CULTURE OPENNESS AS AN ELEMENT OF POSITIVE

Katarzyna Szymańska Anna Walecka achieved by these organisations (Cameron et al., 2003). Given the social nature of the positive potential of the organisation and the complexity of the process as well as its dependence on this context, organisational culture becomes crucial in this case. Based on the main objectives of the positive concept, the development of an organisation is only possible thanks to the creation of positive conditions in which people (members of the organisation) understand their desires and interests as well as determine and achieve their personal goals in full harmony and friendship with other employees. Building the conducive organisational culture is a prerequisite for proper relations in such teams. In addition, given a rapidly changing environment and the problems associated with this process which modern organisations constantly face and the assessment of the previously specified values, organisational culture must be characterised by a certain degree of openness to internal determinants (the internal environment of the organisation) as well as external ones (its external environment) which also determine the positive potential of the organisation. The internal factors include: attitudes, leadership, personality-related behaviour of people who create the given company (managers), interpersonal relationships and trust. In contrast, the accumulation of external factors is the result of the impact of various processes in a dynamically changing environment in which businesses operate (Karaszewski and Lis, 2014).

It can therefore be concluded that, on the one hand, these internal and external factors operate on the basis of the principle of co-dependence, impacting to a large extent the open culture of enterprises, on the other hand, they determine the positive potential of the organisation.

Thus, the open organisational culture is the culture which is characterised by the so-called open space, which refers to the willingness to change (open innovation), high tolerance of uncertainty and flexibility of operation (Szymańska, 2015). Open space is associated with company activities related to the creation of a broad network of cooperation with the entire environment. Opening more widely to the environment in order to be successful in combating the crisis, companies must face the challenges of creating a unique organisational ecosystem, its strategic architecture consisting of deliberately selected partners to support the timely implementation of the agreed strategic objectives (Adamik, 2013). They must become more entrepreneurial and innovative in these activities. Open space should therefore apply not only to customers and suppliers, but also competitors, and in fact generally to companies that have complementary capabilities and do not hesitate to use them in relationships of cooperation with partners necessary for their success, also from the sphere of public administration and science. Willingness to introduce innovative changes is associated with the ability of the enterprise to integrate and organise activities related to the occurrence of new factors in the environment in order to reduce the risk of errors and to take advantage of emerging opportunities. High tolerance of uncertainty 
will be linked with adequate knowledge on the part of managers and employees explaining the given phenomenon that requires a certain action or solution. Flexibility in operation is an important feature/property of the modern enterprises, deliberately and successfully dealing with the situation of dynamic changes in the environment. The open organisational culture will therefore constitute "the backbone" of the enterprise, supporting changes in different areas of the positive potential of the organisation. The main areas include: tangible resources, corporate strategy, organisational structure, internal communication, propensity for innovation, control, human resources management, power and democratisation of management, integration and identification of employees with the company and leadership. The open organisational culture with these characteristics will therefore be created by a variety of activities and initiatives on the part of company owners and employees and determined by a number of internal and external determinants that have an impact on the main areas of positive potential of the organisation.

\section{The methodology of empirical research and characteristics of the respondents}

In order to achieve the set objective, which was an attempt to demonstrate the relationship between the open organisational culture as part of the positive potential of the organisation and the type of crisis occurring in the enterprise, a pilot study of enterprises that were in various types of crisis situations was conducted in 2015 at the Department of Management of Lodz University of Technology. One of the studied aspects was the positive potential of the organisation.

The study included 50 enterprises located in Central Poland. The diagnostic survey method, with the use of the handed-out questionnaire technique, was selected as the research method. An original, specially prepared questionnaire was the research tool.

The study covered primarily limited liability companies, individuals running their own businesses and joint stock companies. The surveyed companies were mostly experienced enterprises, in business for over 10 years $(66 \%)$, operating both domestically (38\%) and internationally (38\%), mainly in the service sector (54\%). In terms of the volume of employment, the companies included small and medium sized enterprises (60\%), as well as large enterprises (40\%).

Managers of enterprises in crisis were the subject of the research $(\mathrm{N}=50)$. The study was completely anonymous and the information derived was treated as confidential.

The study covered mainly medium-level (42\%) and high-level (34\%) managers of both genders. Those were young people, mainly up to 40 years of age (84\%). $70 \%$ of the respondents held a university degree, mostly technical (56\%) and economic (40\%) [1].

Calculations and statistical presentations were made in Microsoft Excel. OF POSITIVE

Katarzyna Szymańska Anna Walecka 
CULTURE OPENNESS AS AN ELEMENT OF POSITIVE

Katarzyna Szymańska Anna Walecka

Figure 1. Type of crisis in the surveyed enterprises

Source: The authors' own compilation based on the study results.

\section{Assessment of organisational culture of the surveyed enterprises in crisis}

The conducted study shows that currently crisis situations are occurring in $64 \%$ of the surveyed enterprises (Figure 1). 20 enterprises are in the situation of the hidden crisis, which means they are experiencing difficulty in achieving business objectives and in management of resources ("temporary difficulties"). 12 enterprises are facing serious financial problems (the overt crisis), while 18 enterprises are not aware of any crisis situations (the potential crisis) at present.

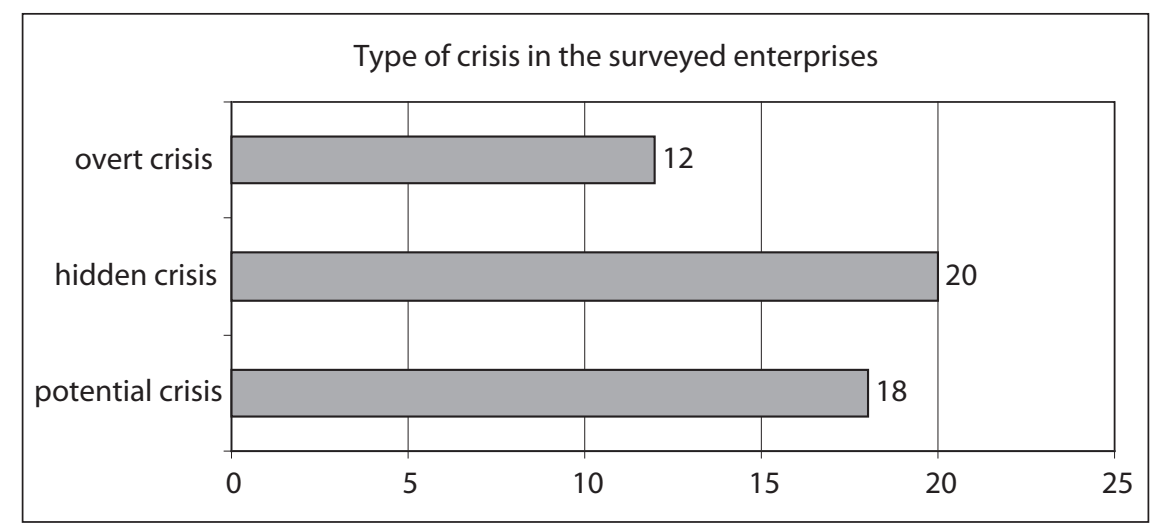

In an attempt at finding the relationship between the situation of the surveyed enterprises (the type of crisis [2]) and the level of their positive potential as well as the open organisational culture, the impact of individual areas of positive organisational potential on the existing organisational culture was analysed. To do this, the respondents were first asked to make a subjective assessment of the degree of openness of their organisational culture.

The assessment of the level of open organisational culture was made for the following crisis phases in the enterprise:

- potential crisis - is a situation that occurs in virtually every enterprise which is adversely affected by various internal and external phenomena. This can pose a risk to the enterprise's operations and objectives pursued. It seems that this kind of situation can be associated with a high degree of cultural closeness of the enterprise;

- hidden crisis - is a situation when difficulties in achieving the enterprise's objectives, which are often perceived as "temporary difficulties", occur. It seems that this may be associated with inappropriate management of resources. This situation is related to the so-called cultural closeness connected with underutilisation of the enterprise's potential and opportunities that arise in its environment. Therefore, the level of cultural 
openness may be so low that it is unable to counteract potential crisis generating factors;

- overt crisis - is a situation of complete overtness of problems that occur in the functioning of the enterprise and threaten its existence in a particular market, which induces cultural openness to take remedial action. In this case, an open organisational culture will be strong enough to take advantage of the enterprise's potential and opportunities that arise in the environment.

For the purposes of the study, the assessment of the level of open organisational culture was carried out on the basis of a questionnaire consisting of closed questions, expressed in the 0-6 scale (where " 1 " means a very low value of the attribute, " 5 " is an indicator of fully open organisational culture, " 0 " means lack of openness, i.e. a high degree of closeness of organisational culture).

The results obtained are presented in Figure 2.

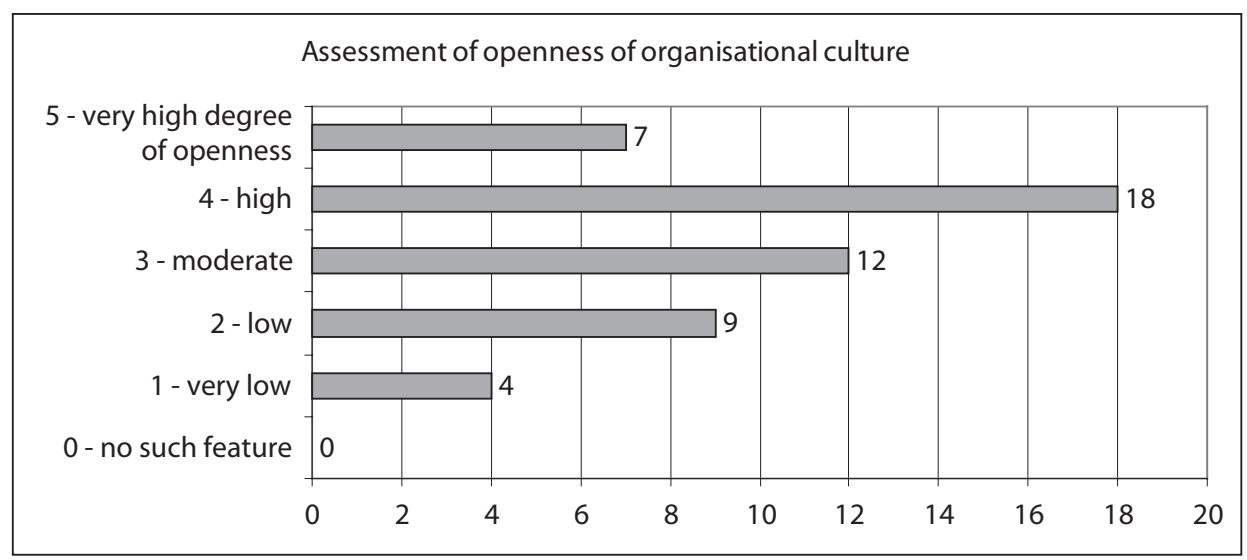

As can be seen in Figure 2, the vast majority of the respondents considered their organisational culture as open ( 25 responses at the level of 4 and 5). 12 respondents assessed the degree of openness at the moderate level and 13 respondents at the low or very low level.

As demonstrated in the theoretical part of the paper, the open organisational culture means the company's willingness to make changes, as well as its high tolerance for uncertainty of operation. It is therefore gratifying to see that as many as half of the respondents considered the culture of their organisation as highly open. This is particularly important in a situation of crisis. Therefore, individual assessments of open culture in relation to the type of crisis faced by the organisation were examined (Figure 3).
CULTURE OPENNESS AS AN ELEMENT OF POSITIVE

Katarzyna Szymańska Anna Walecka

Figure 2. Openness of organisational culture in the surveyed enterprises Source: The authors' own compilation based on the study results. 
CULTURE OPENNESS AS AN ELEMENT OF POSITIVE

Katarzyna Szymańska Anna Walecka

Figure 3. Openness of organisational culture and type of crisis

Source: The authors' own compilation based on the study results.

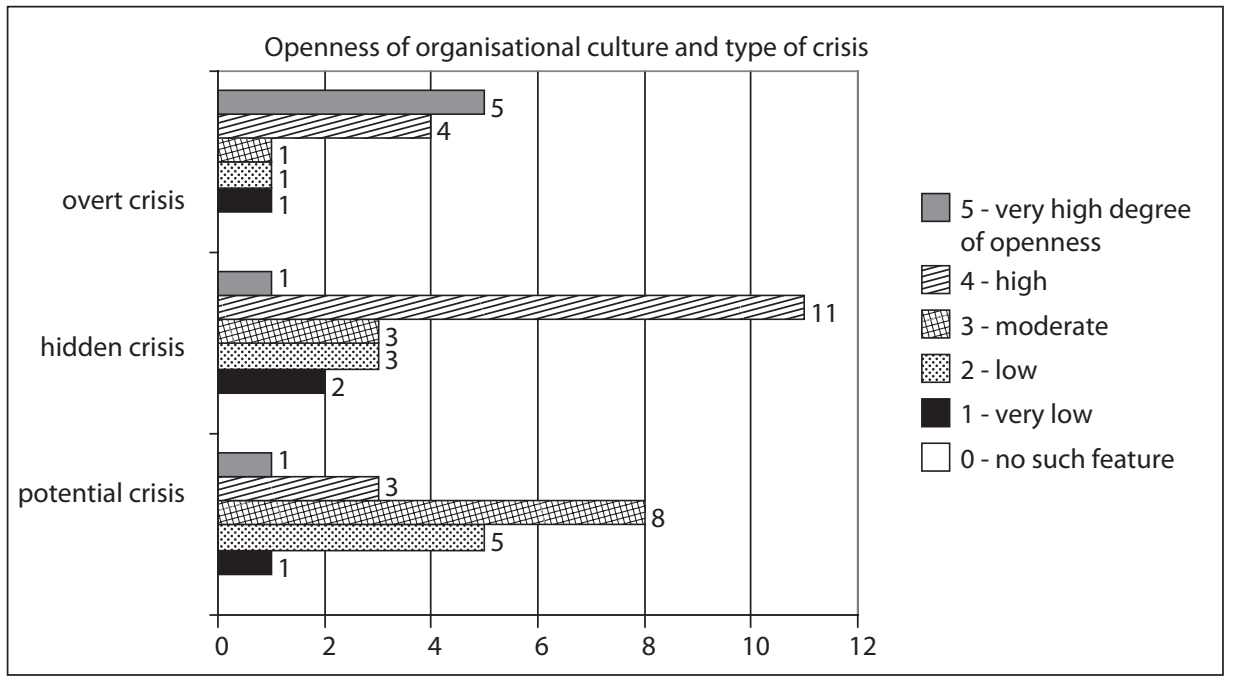

As can be seen in Figure 3, among the enterprises that are currently in the situation of potential crisis (18 companies who are not currently aware of a crisis situation in their organisations), the vast majority consider their own organisational culture as open to a moderate or low degree (14 responses). Among the enterprises in the situation of hidden crisis (20 companies experiencing temporary difficulties in achieving business objectives and in resources management), a certain reversal of the trend can be seen. Only 8 respondents assess the openness of their organisational culture at the medium or low level. 12 respondents consider the organisational culture of their companies to be highly open. Out of 12 companies facing serious financial problems (in the overt crisis), as many as 9 respondents consider their organisation's culture as highly open. This leads to the supposition that that the level of openness of organisational culture is to some extent dependent on the type of crisis faced by the company. It is very reassuring, as in order to deal with the crisis in the company, a variety of remedial actions should be taken, requiring primarily a change in thinking on the part of the management [3]. To help the company overcome the crisis, one should start thinking in a multidimensional and holistic way to flexibly adapt to occurring changes and even to initiate these changes.

Having determined the level of openness of organisational culture of the surveyed companies, the question was asked about the impact of specific areas of the positive potential of the company on the open organisational culture. For this purpose, the respondents were asked to assess the impact of individual factors on each other using a 6-point scale (0-5), where: 0 - no impact, 1 - very little impact, 2 - little impact, 3 - moderate impact, 4 - significant impact, 5 - very significant impact. The results obtained in this area are presented in Table 2. 


\begin{tabular}{lcccccc}
\hline \multirow{2}{*}{ PPO areas } & \multicolumn{7}{c}{ OOC } \\
\cline { 2 - 7 } & $\mathbf{0}$ & $\mathbf{1}$ & $\mathbf{2}$ & $\mathbf{3}$ & $\mathbf{4}$ & $\mathbf{5}$ \\
\hline Tangible resources & 5 & 8 & 5 & 9 & 10 & 13 \\
\hline Strategy & 0 & 0 & 1 & 12 & 22 & 15 \\
\hline Organisational structure & 0 & 1 & 2 & 8 & 27 & 12 \\
\hline Internal communication & 0 & 0 & 5 & 6 & 16 & 23 \\
\hline Propensity for innovation & 0 & 0 & 0 & 4 & 17 & 29 \\
\hline Control & 1 & 2 & 2 & 13 & 23 & 9 \\
\hline Human resources management & 0 & 0 & 1 & 9 & 25 & 15 \\
\hline Power and democratisation of management & 0 & 0 & 2 & 12 & 27 & 9 \\
\hline $\begin{array}{l}\text { Integration and identification of employees } \\
\text { with the enterprise }\end{array}$ & 0 & 0 & 0 & 10 & 23 & 17 \\
\hline Leadership & 0 & 0 & 0 & 8 & 32 & 10 \\
\hline
\end{tabular}

Based on Table 2, according to the respondents, the factors that shape the open organisational culture to a significant and very significant degree include: the enterprise's propensity for innovation (46 responses altogether), the type of leadership (42 responses), methods of human resources management (40 responses), a degree of integration and identification of employees with the enterprise (40 responses), quality of internal communication (39 responses), and the organisational structure (39 responses).

After examining the impact of specific areas of the positive potential of the organisation on the open organisational culture, the results obtained were compared to the type of crisis that the enterprises were facing. The results obtained are presented in Tables 3-5.

\begin{tabular}{|c|c|c|c|c|c|c|}
\hline \multirow[t]{2}{*}{ PPO areas } & \multicolumn{6}{|c|}{$\begin{array}{l}\text { Openness of organisational culture of the } \\
\text { enterprise in the potential crisis }\end{array}$} \\
\hline & $\mathbf{0}$ & 1 & 2 & 3 & 4 & 5 \\
\hline Tangible resources & 5 & 4 & 1 & 4 & 2 & 2 \\
\hline Strategy & 0 & 0 & 0 & 7 & 8 & 3 \\
\hline Organisational structure & 0 & 1 & 0 & 2 & 12 & 3 \\
\hline Internal communication & 0 & 0 & 5 & 2 & 4 & 7 \\
\hline Propensity for innovation & 0 & 0 & 0 & 2 & 4 & 12 \\
\hline Control & 1 & 2 & 2 & 7 & 6 & 0 \\
\hline Human resources management & 0 & 0 & 1 & 5 & 8 & 4 \\
\hline Power and democratisation of management & 0 & 0 & 0 & 6 & 12 & 0 \\
\hline $\begin{array}{l}\text { Integration and identification of employees } \\
\text { with the enterprise }\end{array}$ & 0 & 0 & 0 & 2 & 12 & 4 \\
\hline Leadership & 0 & 0 & 0 & 5 & 13 & 0 \\
\hline
\end{tabular}

CULTURE OPENNESS AS AN ELEMENT OF POSITIVE

Katarzyna Szymańska Anna Walecka

Table 2. Open organisational culture (OOC) and areas of Positive Potential of the

Organisation

Source: The authors' own compilation based on the study results.

Table 3. Open organisational culture and areas of Positive Potential of the Organisation in the potential crisis Source: The authors' own compilation based on the study results. 
CULTURE OPENNESS AS AN ELEMENT OF POSITIVE

Katarzyna Szymańska Anna Walecka

Table 4. Open organisational culture and areas of Positive Potential of the Organisation in the hidden crisis

Source: The authors' own compilation based on the study results.

Table 5. Open organisational culture and areas of Positive Potential of the Organisation in the overt crisis

Source: The authors' own compilation based on the study results.
PPO areas

Openness of organisational culture of the enterprise in the hidden crisis

\begin{tabular}{lllllll}
\cline { 2 - 7 } & $\mathbf{0}$ & $\mathbf{1}$ & $\mathbf{2}$ & $\mathbf{3}$ & $\mathbf{4}$ & $\mathbf{5}$ \\
\hline Tangible resources & 0 & 3 & 2 & 5 & 4 & 6 \\
\hline Strategy & 0 & 0 & 1 & 4 & 10 & 5 \\
\hline Organisational structure & 0 & 0 & 1 & 2 & 10 & 7 \\
\hline Internal communication & 0 & 0 & 0 & 2 & 8 & 10 \\
\hline Propensity for innovation & 0 & 0 & 0 & 2 & 10 & 8 \\
\hline Control & 0 & 0 & 0 & 6 & 13 & 1 \\
\hline Human resources management & 0 & 0 & 0 & 2 & 12 & 6 \\
\hline Power and democratisation of management & 0 & 0 & 2 & 5 & 10 & 3 \\
\hline Integration and identification of employees & 0 & 0 & 0 & 6 & 7 & 7 \\
with the enterprise & 0 & 0 & 0 & 3 & 17 & 0 \\
\hline Leadership & & & & & &
\end{tabular}

$* \mathrm{~N}=20$

\section{Openness of organisational culture of the} enterprise in the overt crisis

\begin{tabular}{|c|c|c|c|c|c|c|}
\hline \multirow[t]{2}{*}{ PPO areas } & \multicolumn{6}{|c|}{ enterprise in the overt crisis } \\
\hline & $\mathbf{0}$ & 1 & 2 & 3 & 4 & 5 \\
\hline Tangible resources & 0 & 1 & 2 & 0 & 4 & 5 \\
\hline Strategy & 0 & 0 & 0 & 1 & 4 & 7 \\
\hline Organisational structure & 0 & 0 & 1 & 4 & 5 & 2 \\
\hline Internal communication & 0 & 0 & 0 & 2 & 4 & 6 \\
\hline Propensity for innovation & 0 & 0 & 0 & 0 & 3 & 9 \\
\hline Control & 0 & 0 & 0 & 0 & 4 & 8 \\
\hline Human Resources Management & 0 & 0 & 0 & 2 & 5 & 5 \\
\hline Power and democratisation of management & 0 & 0 & 0 & 1 & 5 & 6 \\
\hline $\begin{array}{l}\text { Integration and identification of employees } \\
\text { with the enterprise }\end{array}$ & 0 & 0 & 0 & 2 & 4 & 6 \\
\hline Leadership & 0 & 0 & 0 & 0 & 2 & 10 \\
\hline
\end{tabular}

$* \mathrm{~N}=12$

As shown in Tables $3-5$, the factors that - according to the respondents shape the open organisational culture to a high or very high degree include:

- in the case of enterprises in the situation of potential crisis: the company's propensity for innovation, the degree of integration and identification of employees with the company and its organisational structure; 
- in the case of enterprises in the situation of hidden crisis: the company's propensity for innovation, the manner in which human resources are managed, internal communication, its organisational structure and leadership;

- in the case of enterprises in the situation of overt crisis: the company's propensity for innovation, leadership, power and democratisation of management, exercising the control function or the company's strategy.

It appears, therefore, that - despite the presence of certain differences in the assessment of individual factors - the attitude of the management is according to the respondents - an extremely important aspect in terms of openness of organisational culture. The management must take various remedial actions depending on the type of crisis occurring in the organisation. It can therefore be concluded that a proper manner of governance, decentralisation of management, as well as effective communication within the organisation provide an opportunity to create such a team of employees that will identify themselves with the organisation. Only then employees will be willing to take innovative and creative actions, so important to overcome a crisis occurring in the given organisation.

\section{Conclusions}

The paper presents the results of the pilot survey conducted in 50 companies located in Central Poland. The results obtained prompt to draw the conclusion that there is a relationship between the open organisational culture which is part of the positive potential of the organisation and the type of crisis occurring in the enterprise. Among the enterprises that were in the situation of potential crisis, the vast majority assessed their own organisational culture as moderately open and not very open. The enterprises in the situation of hidden crisis mostly declared the existence of open organisational culture. Similar observations were made by the companies facing serious financial problems (in the situation of overt crisis). The vast majority of the surveyed companies considered their own organisational culture as highly open. It can be therefore understood as the so-called positive state of the organisation which allows the enterprise to overcome various problems that stand in the way of its success.

Thus, it should be concluded that the creation of open organisational culture which is part of the positive potential of the organisation is one of the key elements of enterprises' activity. Companies need to deal with various problems generated by a dynamically changing environment. In such situations, it is important to make certain changes also in their organisational culture while taking remedial (anticrisis) actions. Carrying out its modifications, however, is a difficult and important management process (Walecka, 2014b). Nevertheless, it is possible, especially when such a culture exhibits characteristics of openness and is at the same time supported by the determinants of the positive potential of the organisation. 
CULTURE OPENNESS AS AN ELEMENT OF POSITIVE

Katarzyna Szymańska Anna Walecka
The authors of the paper are aware that the study conducted is somewhat limited. First of all, the process of data collection was carried out among only 50 companies (a pilot study) and solely among the managers of the surveyed enterprises. Although the elements of the research used are considered to be important sources of data on organisational culture and crisis (Gregory et al., 2009), the authors realise that the best results are obtained by deriving data from all the employees of the given organisation. Such an assumption motivates to focus on a wider survey sample which will cover the entire organisational structure of the enterprise. This will allow the construction of a model of organisational culture determined by a specific type of crisis, which will indicate the direction of further empirical research.

\section{Notes}

[1] The presented results form only part of broader research on organisational culture of enterprises and the phenomenon of crisis in an organisation conducted by the Faculty of Management at Lodz University of Technology.

[2] The division of crisis into potential, hidden and overt was proposed by Nogalski and Macinkiewicz (2004, p. 14).

[3] Detailed characterisation of remedial actions in a crisis situation can be found, among others, in Walecka, 2014a, pp. 34-40.

\section{References}

Adamik, A. (2013), "A partnering approach to extending the business base through cooperation with competitors (coopetition) - is it an option for SMEs?", in: Zaharim, A., Rodrigues, R. G. (Eds.), Recent Advances in Management, Marketing and Finance, Business and Economics Series, No. 4, WSEAS Press, Cambridge, pp. 59-65.

Cameron, K. S. (2008), Positive Leadership: Strategies for Extraordinary Performance, Berrett Kohler, San Francisco.

Cameron, K. S., Dutton, J. E., Quinn, R. E. (Eds.) (2003), Positive Organizational Scholarship. Foundation of a New Discipline, Berrett Kohler, San Francisco.

Chong, H. S., Goh, G. G. G., Eze, U. C. (2009), "Knowledge management enablers toward successful new product development: A case study in a semiconductor manufacturing firm", Journal of Knowledge Management Practice, Vol. 10 No. 4, available at: http://tlainc.com/articl206.htm (accessed 10 September 2015).

Glińska-Neweś, A, Haffer, R. (2014), "Pozytywne Zarządzanie jako nowa perspektywa organizacji”, in: Wachowiak, P., Winch, S. (Eds.), Granice w zarzadzaniu kapitałem ludzkim, Oficyna wydawnicza Szkoła Głowna w Warszawie, Warszawa, pp. 172-181.

Glińska-Neweś, A. (2010), "Pozytywny Potencjał Organizacji jako prorozwojowa architektura zasobów przedsiębiorstwa”, in: Stankiewicz, J. M., (Ed.), Pozytywny Potencjał Organizacji. Wstęp do użytecznej teorii zarządzania, TNOiK Dom Organizatora, Toruń, pp. 37-52. 
Gregory, B. T., Harris, S. G., Armenakis, A. A., Shook, Ch. L. (2009), "Organizational culture and effectiveness: A study of values, attitudes and organizational outcomes", Journal of Business Reserch, Vol. 62 No. 7, pp. 673-679. DOI: http://dx.doi. org/10.1016/j.jbusres.2008.05.021

CULTURE OPENNESS

AS AN ELEMENT OF POSITIVE

Katarzyna Szymańska Anna Walecka

Karaszewski, R., Lis, A. (2014), "Wewnątrzorganizacyjne uwarunkowania rozwoju kluczowych obszarów pozytywnego potencjału organizacji”, in: Wachowiak, P., Winch, S. (Eds.), Granice w zarzadzaniu kapitałem ludzkim, Warszawa: Oficyna wydawnicza Szkoła Główna, Warszawa, pp. 183-197.

Kulkarni, U. R., Ravindran, S., Freeze, R. A. (2007), "Knowledge management success model”, Management \& Data Systems, Vol. 106 No. 6, pp. 55-70.

Nogalski, B., Macinkiewicz, H. (2004), Zarzqdzanie antykryzysowe przedsiębiorstwem: pokonać kryzys $i$ wygrać, Difin, Warszawa.

Szymańska, K. (2015), Kryzys gospodarczy recepta na otwarta kulturę organizacyjna przedsiębiorstw, Marketing i rynek, Warszawa.

Walecka, A. (2014a), Managers' Behaviour Determinants in the Enterprise Crisis Situation, A Series of Monographs, Lódź.

Walecka, A. (2014b), "Zmiany w kulturze organizacyjnej w wyniku kryzysu w przedsiębiorstwie”, in: Szymańska, K., (Ed.), Kultura organizacyjna we współczesnych organizacjach, Monografie Politechniki Łódzkiej, Łódź, pp. 23-50.

Wong, K. Y. (2005), "Critical success factors for implementing knowledge management in small and medium enterprises", Industrial Management \& Data Systems, Vol. 95 No. 3, pp. 261-279.

Yeh, Y. J., Lai, S. Q., Ho, C. T. (2006), "Knowledge management enablers: A case study", Industrial, Management \& Data Systems, Vol. 106 No. 6, pp. 793-810. DOI: http:// dx.doi.org/10.1108/02635570610671489 